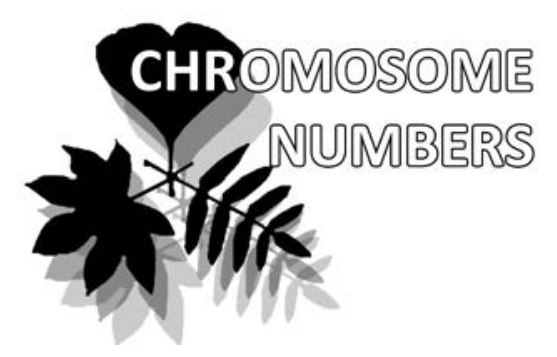

Nina S. Probatova ${ }^{1 *}$

e-mail: probatova@ibss.dvo.ru

Sergey G. Kazanovsky ${ }^{2}$

e-mail: skazanovsky@mail.ru

${ }^{1}$ Federal Scientific Center for the East Asia Terrestrial Biodiversity FEB RAS,

Vladivostok, Russia

${ }^{2}$ Siberian Institute of Plant Physiology \& Biochemistry SB RAS, Irkutsk, Russia

* corresponding author

Manuscript received: 13.03 .2018

Review completed: 25.03.2018

Accepted for publication: 15.04.2018

Published online: 19.04 .2018

\section{Chromosome numbers in some vascular plant species from the Crimea}

\author{
Nina S. Probatova ${ }^{1 *} \&$ Sergey G. Kazanovsky ${ }^{2}$
}

\begin{abstract}
A B S T R A C T
Chromosome numbers (2n) for 42 species of vascular plants of 35 genera from 10 families: Apiaceae: Myrrhoides; Asteraceae: Jurinea, Podospermum, Pterotheca, Steptorhamphus, Tragopogon; Brassicaceae: Alyssum, Camelina, Diplotaxis, Matthiola; Caryophyllaceae: Melandrium, Oberna; Geraniaceae: Geranium; Lamiaceae: Salvia; Poaceae: Aegilops, Anisantha, Arrhenatherum, Avena, Bromopsis, Bromus, Dactylis, Dasypyrum, Hordeum, Koeleria, Lolium, Poa, Rostraria, Sclerochloa, Stipa, Trachynia, Vulpia; Rosaceae: Potentilla, Poterium; Rubiaceae: Galium; Violaceae: Viola, from Crimean Peninsula and Republic of Crimea are presented. For the Crimean endemic species Jurinea sordida Steven, Salvia rhodantha Zefir. and Potentilla jailae Juz. we studied the $\mathrm{CNs}$ for the first time. Most chromosome data are revealed first in Crimean plants.
\end{abstract}

K e y w o r d s : chromosome numbers, vascular plants, flora, Crimean Peninsula, Republic of Crimea, Russia

\section{P E 3 Ю M E}

Пробатова Н.С., Казановский С.Г. Числа хромосом некоторых виАов сосудистых растений из Крыма. Приводятся числа хромосом (2n) ААя 42 видов из 35 родов и 10 семейств: Apiaceae: Myrrhoides; Asteraceae: Jurinea, Podospermum, Pterotheca, Steptorhamphus, Tragopogon; Brassicaceae: Alyssum, Camelina, Diplotaxis, Matthiola; Caryophyllaceae: Melandrium, Oberna; Geraniaceae: Geranium; Lamiaceae: Salvia; Poaceae: Aegilops, Anisantha, Arrhenatherum, Avena, Bromopsis, Bromus, Dactylis, Dasypyrum, Hordeum, Koeleria, Lolium, Poa, Rostraria, Sclerochloa, Stipa, Trachynia, Vulpia; Rosaceae: Potentilla, Poterium; Rubiaceae: Galium; Violaceae: Viola. Впервые исследованы в кариологическом отношении эндемичные Аля Крыма виды Jurinea sordida Steven, Salvia rhodantha Zefir. и Potentilla jailae Juz. Большинство Аанных по числам хромосом приводятся Аля Крыма впервые. К $\boldsymbol{\Lambda}$ юче вые слова: числа хромосом, сосудистые растения, флора, полуостров Крым, Республиика Крым, Россия
The original vascular flora of the Crimea, which includes 2536 spontaneous taxa of specific and sub-specific rank, belonging to 760 genera (Yena 2012) is poorly investigated as to chromosome numbers up-to-date, except the representatives of the Poaceae Family (see Prokudin et al. 1977). Besides there are several $\mathrm{CN}$ data from Crimea for some species in Tonyan (1968), Patudin et al. (1975), Sokolovskaya \& Probatova (1976, 1978), Magulaev (1984, 1986), Glagoleva \& Zemskova (1985), Alexeev et al. (1987, 1988), Probatova \& Seledets (2008), Probatova et al. (2015, 2016).

We present results of chromosome number $(\mathrm{CN})$ study in 42 species of vascular plants from the Crimean Peninsula (Fig. 1). Plants were collected by S.G. Kazanovsky in the field. As to Poaceae, our contribution continues the recent publications concerning the Poaceae of Russia (Probatova, Seledets \& Barkalov 2015; Probatova, Barkalov \& Chernyagina 2016; Probatova, Barkalov \& Agafonov 2017), and these data will be added to the book "Poaceae of Russia" by Tzvelev \& Probatova (in press), from where we took the information about species. Chromosome countings were made on squashed preparations of root tips taken and fixed with Carnoy's solution by N.S. Probatova from seedlings obtained through herbarium specimens. Preparations were stained with iron hematoxylin. Voucher specimens are preserved in the Herbarium VLA, Vladivostok, and in Herbarium IRK, Irkutsk. First CN data for the species are indicated by asterisk (*). The number of the dot on the map follows the number of voucher specimen. Brief information about species studied is given.

\footnotetext{
APIACEAE

Myrrhoides nodosa (L.) Cannon, $2 \mathrm{n}=22$

Republic of Crimea, surroundings of Yalta, Nikita settlement, near Massandra palace, Massandrovskie grottos, $358 \mathrm{~m}$ alt., big lumpy rocky outcrops, 5 Jun 2016, coll. S.G. Kazanovsky 13184: 1 (IRK, VLA). Species distribution: Euro-Mediterranean. In light forests, among shrubs, wet places at the rocks, sometimes on roadsides. Described from Italy (Sicily). Monotypic genus. In many cases the $\mathrm{CN} 2 \mathrm{n}=22$ is reported in the literature. No previous CN counts from Crimea. Diploid (2x), $\mathrm{x}=11$.
} 


\section{ASTERACEAE}

*Jurinea sordida Steven, $2 \mathrm{n}=34$

Republic of Crimea, surroundings of Feodossia, Kurortnoe settlement, the Karadagskii nature reserve RAS, near the rock Zolotye Vorota, $226 \mathrm{~m}$ alt., dry rocky slope, 27 May 2016, coll. S.G. Kazanovsky 13190: 2 (IRK, VLA). Distribution: endemic of Crimea. On cretaceous limestone rock outcrops. Described from Crimea. In Yena (2012) it was included in J. roegneri $\mathrm{K}$. Koch. The close relative J. mollis (L.) Rchb. has also $2 \mathrm{n}=34$ (Marhold et al. 2007), but sometimes $2 \mathrm{n}=30,36$ (see Fedorov 1969, Májovský et al. 1987). In polybasic genus Jurinea Cass. $\mathrm{x}=8,9,15,17$ (the basic CNs are given here and after according to Májovský et al. 1987). Diploid (2x), $\mathrm{x}=17$.

Podospermum laciniatum (L.) DC. (Scorzonera laciniata L.), $2 \mathrm{n}=14$

Republic of Crimea, Feodossia city, near the Genujezskaya fort, $51 \mathrm{~m}$ alt., forb steppe, 26 May 2016, coll. S.G. Kazanovsky 13255: 4 (IRK, VLA). Distribution: Europe, SW Asia. Steppes, stony slopes. Described from W Europe. The $\mathrm{CN}$ is constant, there are many reports in the literature (as Scorzonera and Podospermum): $2 \mathrm{n}=14$ (IPCN Chromosome Reports: www.tropicos.org). Probably the first CN report from Crimea. Diploid (2x), $\mathrm{x}=7$.

Pterotheca sancta (L.) C. Koch (Lagoseris sancta (L.) K. Malý, Crepis sancta (L.) Babc.), $2 \mathrm{n}=10$

Republic of Crimea, Sudak town, the Genujezskaya fort, near Konsul'skaya tower, $111 \mathrm{~m}$ alt., rocky slope, 29 May 2016, coll. S.G. Kazanovsky 13171: 3 (IRK, VLA); Republic of Crimea, surroundings of Feodossia, Kurortnoe settlement, the Karadagskii nature reserve RAS, near the rock Zolotye Vorota, $226 \mathrm{~m}$ alt., dry rocky slope with steppe vegetation, 27 May 2016, coll. S.G. Kazanovsky 13200: 2 (IRK, VLA). Distribution: S Europe, Caucasus, SW Asia. Steppes, dry stony slopes and rocks; as alien - in waste places. Described from Middle East. Many $\mathrm{CN}$ reports (see Fedorov 1969): $2 \mathrm{n}=10$ (rarely $2 \mathrm{n}=10+1-2 \mathrm{~B}$ ), but none from Crimea. Diploid (2x), $\mathrm{x}=5$.

Steptorhamphus tuberosus (Jacq.) Grossh. (Lactuca tuberosa Jacq.), $2 \mathrm{n}=16$

Republic of Crimea, surroundings of Yalta, near Foros settlement, $145 \mathrm{~m}$ alt., Quercus, Pinus and Juniperus forest on the S slope, at the forest road, 11 Jun 2016, coll. S.G. Kazanovsky 13256: 6 (IRK). Distribution: S Europe, SW Asia (mostly Mediterranean). On rocks and screes. Described from S Europe (Greece?). We found 6 reports of $2 \mathrm{n}=16$ (see Fedorov 1969; IPCN Chromosome Reports: www. tropicos.org). First $\mathrm{CN}$ report from Crimea. Diploid (2x), $\mathrm{x}$ $=8$. In the related genus Lactuca the basic $\mathrm{CN} \mathrm{x}=9$.

Tragopogon dubius Scop., $2 \mathrm{n}=12$

Republic of Crimea, surroundings of Feodossia, Kurortnoe settlement, the Karadagskii nature reserve RAS, near the rock Zolotye Vorota, $226 \mathrm{~m}$ alt., dry rocky slope, 27 May 2016, coll. S. G. Kazanovsky 13187: 2 (IRK, VLA). Distribution: Caucasian-Mediterranean; alien in N America. Stony (limestone) and melkozem slopes and rocks, glades and forest edges, steppes and along roadsides. Described from Italy. Many $\mathrm{CN}$ reports in the literature $(2 \mathrm{n}=12)$, but none from Crimea. Diploid (2x), $x=6$.



Figure 1 Study area. Dots with numbers from 1 to 9 are the sampling plot locations (according to numbering in the text)

\section{BRASSICACEAE}

\section{Alyssum trichostachyum Rupr., 2n $=48$}

Republic of Crimea, Sudak town, the Genujezskaya fort, on the slope at the fort wall, $89 \mathrm{~m}$ alt., rocky slope, 26 May 2016, coll. S.G. Kazanovsky 13185: 3 (IRK, VLA). Distribution: Crimean-Caucasian. On dry slopes. Described from $\mathrm{N}$ Caucasus. For $A$. trichostachyum $2 \mathrm{n}=16,24,32$ were known (see Fedorov 1969), and $2 \mathrm{n}=48$ was reported from Bulgaria (Anchev 1991 - cit. by Index ..., 1994). Perhaps this hexaploid cytotype $(2 \mathrm{n}=48)$ is distributed around the Black Sea. The diploid cytotype $(2 \mathrm{n}=16)$ was revealed from Krasnodarskii Krai (Magulaev 1984). No previous $\mathrm{CN}$ data from Crimea. Hexaploid cytotype (6x), $\mathrm{x}=8$ (in general - the variable ploidy).

\section{Camelina rumelica Velen., $2 \mathrm{n}=12$}

Republic of Crimea, surroundings of Feodossia, Kurortnoe settlement, the Karadagskii nature reserve RAS, near the rock Chertov Palets, $374 \mathrm{~m}$ alt., grass-forb steppe, 27 May 2016, coll. S.G. Kazanovsky 13203: 2 (IRK). Distribution: S Europe, SW Asia; alien in NW Russia. Steppes, rarely on railroads. Described from Bulgaria. We found only one $\mathrm{CN}$ report of $2 \mathrm{n}=12$ for $C$. rumelica, but also $2 \mathrm{n}=26$ and 40 reported by Májovský et al. (1987). Diploid (2x), x 6. Polybasic genus (and species ?): $\mathrm{x}=6,10,13$. No CN data reported previously from Crimea.

\section{Diplotaxis tenuifolia (L.) DC., $2 \mathrm{n}=22$}

Republic of Crimea, Feodossia city, near the Genujezskaya fort, $51 \mathrm{~m}$ alt., ruderal vegetation among the ruins of the fort, 26 May 2016, coll. S.G. Kazanovsky 13205: 4 (IRK, VLA). Distribution: Europe, SW Asia; alien elsewhere. On roadsides, in settlements. Described from W Europe. The $\mathrm{CN} 2 \mathrm{n}=22$ is the most common for D. tenuifolia (see Májovský et al. 1987), and it was revealed also from Krasnodarskii Krai (Magulaev 1984). Diploid (2x), $x=11$. No previous $\mathrm{CN}$ data from Crimea. Polybasic genus $(\mathrm{x}=7,9,10,11)$.

Matthiola odoratissima (M. Bieb.) W.T. Aiton, $2 \mathrm{n}=12$

Republic of Crimea, surroundings of Yalta, Nikita settlement, near Massandra palace, Massandrovskie grottos, $358 \mathrm{~m}$ alt., Pinus and Quercus forest on big lumpy rocky outcrops, 5 Jun 2016, coll. S.G. Kazanovsky 13163: 1 (IRK, VLA). Distribution: S Europe - SW Asia. On clay and 
limestone slopes. Described from "Caucasus" and Crimea. M. odoratissima was studied from Krasnodarskii Krai and from Republic of Daghestan (2n = 12 - Magulaev 1984). The genus Mattiola R. Br. is characterized by $\mathrm{x}=6$ and 7 . Diploid (2x), $\mathrm{x}=6$.

\section{CARYOPHYLLACEAE \\ Melandrium latifolium (Poir.) Maire, $2 \mathrm{n}=24$}

Republic of Crimea, surroundings of Feodossia, Kurortnoe settlement, the Karadagskii nature reserve RAS, near the Biological station, $219 \mathrm{~m}$ alt., dry broadleaved (Pistacia and Quercus) forest, 27 May 2016, coll. S. G.Kazanovsky 13195: 2 (IRK, VLA). Distribution: E European-Caucasian-Mediterranean. In steppes, forest edges and clearings with steppe vegetation, on cretaceous and limestone outcrops, rarely at roadsides. Described from $\mathrm{N}$ Africa. There are several CN reports: $2 \mathrm{n}=24$ (see Marhold et al. 2007 - as Silene). No previous CN counts from Crimea. Diploid $(2 \mathrm{x}), \mathrm{x}=12$.

\section{Oberna commutata (Guss.) Ikonn., $2 \mathrm{n}=24$}

Republic of Crimea, surroundings of Yalta, Nikita settlement, near Massandra palace, Massandrovskie grottos, 358 m alt., Quercus forest with shrubs on big lumpy placer, 5 Jun 2016, coll. S.G. Kazanovsky 13191: 1 (IRK, VLA). Distribution: Caucasian-Mediterranean. Rocky and loamy slopes, forest edges and clearings. Described from Italy (Sicily). This species is often considered in the genus Silene, where $2 \mathrm{n}=24$ is known in most cases. For O. commutata $2 \mathrm{n}$ $=24$ is known from Armenia (Nazarova \& Gukassian 2004 - as Silene). No previous CN counts from Crimea. Diploid $(2 \mathrm{x}), \mathrm{x}=12$.

\section{GERANIACEAE}

\section{Geranium lucidum L., 2n $=40$}

Republic of Crimea, surroundings of Feodossia, Kurortnoe settlement, the Karadagskii nature reserve RAS, near Biological station, $219 \mathrm{~m}$ alt., broadleaved (Pistacia and Quercus) forest, moist plot, 27 May 2016, coll. S.G. Kazanovsky 13186: 2 (IRK, VLA). Distribution: Europe, Caucasus, SW and Central Asia. In forests, usually on shaded stony slopes, on rocks and screes. Described from Europe. The $\mathrm{CN} 2 \mathrm{n}=40$ is the most common for G. lucidum, but $2 \mathrm{n}=$ 20 also occurs. No previous $\mathrm{CN}$ data from Crimea. Tetraploid $(4 \mathrm{x}), \mathrm{x}=10$. The genus Geranium L. is polybasic $(\mathrm{x}=$ $7,10,13)$.

\section{Geranium molle L., 2n $=26$}

Republic of Crimea, Sudak town, the Genujezskaya fort, at the wall of the fort, $89 \mathrm{~m}$ alt., rocky slope, 26 May 2016, coll. S.G. Kazanovsky 13197: 3 (IRK, VLA). Distribution: Europe, Caucasus, SW Asia; sometimes as alien. Forest glades, steppe stony slopes, on rocks and screes. as a weed in loaded meadows and fields, in settlements, along the roads. Described from Europe. Multiple $\mathrm{CN}$ counts give $2 \mathrm{n}=26$ (see Fedorov 1969, Májovský et al. 1987). No previous $\mathrm{CN}$ counts from Crimea. Diploid (2x), $\mathrm{x}=13$.

\section{Geranium pusillum L., 2n $=26$}

Republic of Crimea, Sudak town, the Genujezskaya fort, the rocks near the Konsul'skaya tower, $111 \mathrm{~m}$ alt., rocky slope, 29 May 2016, coll. S.G. Kazanovsky 13198: 3
(IRK, VLA). Distribution: E Europe, Caucasus, SW Asia; alien in Arctic Russia and in Urals. Meadow-steppe stony slopes, forest glades, as a weed in disturbed meadows and fields, in settlements and roadsides. Described from Europe. Multiple CN counts: 2n = 26 (see Fedorov 1969, Májovský et al. 1987). No previous CN counts from Crimea. Diploid (2x), $\mathrm{x}=13$.

\section{LAMIACEAE}

*Salvia rhodantha Zefir., $2 \mathrm{n}=36$

Republic of Crimea, surroundings of Yalta, near Nikita settlement, the coast of the Black Sea, $72 \mathrm{~m}$ alt., the Pinus and Juniperus forest, 3 Jun 2016, coll. S.G. Kazanovsky 13193: 1 (IRK, VLA). Distribution: endemic of Crimea. Described from Crimea (Zefirov 1960). Dry stony slopes, along roads, in coastal zone. In Yena (2012) this species was included in $S$. verbenaca $L$. However, in $S$. verbenaca $2 n=14$ is known (Patudin et al. 1975), and as S. verbenacea (?) L. $-2 \mathrm{n}=$ 42, 54, 64, also some aneuploids (see Fedorov 1969; IPCN Chromosome Reports: www.tropicos.org.). The CN for $S$. rhodantha is revealed first, on the specimen collected near its "locus classicus". Hexaploid (6x), $\mathrm{x}=6$. Further studies are needed. The genus Salvia L. is polybasic ( $\mathrm{x}=6,7,8,9,11$, 15, 17, 19).

\section{POACEAE}

\section{Aegilops ovata L., $2 \mathrm{n}=28$}

Russia, Crimea Peninsula, Sevastopol' city, the historical-archaeological state museum-reserve Khersones Tavricheskii, near the beach "Solnechnyi", $58 \mathrm{~m}$ alt., the grass-forb stony steppe on the slope, 7 Jun 2016, coll. S.G. Kazanovsky 13215: 5 (IRK, VLA); Republic of Crimea, surroundings of Feodossia, Kurortnoe settlement, the Karadagskii nature reserve RAS, near Biological station, $219 \mathrm{~m}$ alt., broadleaved (Pistacia and Quercus) forest, moist plot, 27 May 2016, coll. S.G. Kazanovsky 13234: 2 (IRK, VLA). Distribution: S Europe - SW Asia. On stony and loamy slopes, along roadsides. Described from $S$ Europe. Several CN counts from Crimea: $2 \mathrm{n}=28$ (see Prokudin et al. 1977). Tetraploid (4x), $x=7$.

\section{Anisantha rubens (L.) Nevski, 2n $=28$}

Russia, the Crimean Peninsula, Sevastopol' city, the historical-archaeological state museum-reserve Khersones Tavricheskii, $55 \mathrm{~m}$ alt., in the ruins of the ancient settlement, 7 Jun 2016, coll. S.G. Kazanovsky 13240: 5 (IRK, VLA). Distribution: S Europe, SW Asia, N Africa; alien in many other countries. Stony and loamy slopes, sands, screes, along roadsides. Described from Spain. No previous $\mathrm{CN}$ counts from Crimea. Tetraploid (4x), $\mathrm{x}=7$.

\section{Anisantha sterilis (L.) Nevski, 2n = 14}

Republic of Crimea, surroundings of Feodossia, Kurortnoe settlement, the Karadagskii nature reserve RAS, near the Biological station, $219 \mathrm{~m}$ alt., dry broadleaved (Pistacia and Quercus) forest, 27 May 2016, coll. S.G. Kazanovsky 13150: 2 (IRK, VLA).

\section{Anisantha sterilis var. velutina (Volkart ex Hegi) Tzvelev,
$2 \mathrm{n}=14$}

Republic of Crimea, Sudak town, the Genujezskaya fort, near Konsul'skaya tower, $111 \mathrm{~m}$ alt., at the bottom 
of the rock, 29 May 2016, coll. S.G. Kazanovsky 13241: 3 (IRK, VLA). Distribution of the species: Euro-Mediterranean. On the slopes, waste places, along roadsides. Described from Europe. Several CN counts from Crimea: $2 \mathrm{n}=$ 14 (see Prokudin et al. 1977). Diploid (2x), $x=7$.

Anisantha tectorum (L.) Nevski var. hirsuta (Regel) Tzvelev, $2 \mathrm{n}=14$

Republic of Crimea, Feodossia city, Mitridat Mt., $71 \mathrm{~m}$ alt., sight place, the ruderal vegetation, 26 May 2016, coll. S.G. Kazanovsky 13151: 4 (IRK, VLA); Russia, Crimean Peninsula, Sevastopol' city, the historical-archaeological state museum-reserve Khersones Tavricheskii, near the beach "Solnechnyi", $58 \mathrm{~m}$ alt., the grass-forb stony steppe on the slope, 7 Jun 2016, coll. S.G. Kazanovsky 13189: 5 (IRK, VLA); Russia, Crimean Peninsula, Sevastopol' city, the historical-archaeological state museum-reserve Khersones Tavricheskii, $55 \mathrm{~m}$ alt., in the ruins of the ancient settlement, 7 Jun 2016, coll. S.G. Kazanovsky 13196: 5 (IRK, VLA). Distribution: Euro-Mediterranean, as alien in many countries and regions throughout the world. On stony and loamy slopes, fixed sands, pebbles, waste places, in steppes, along roadsides. Described from Europe. Several CN counts from Crimea: $2 \mathrm{n}=14$ (see Prokudin et al. 1977). Diploid (2x), $\mathrm{x}=7$. Var. hirsuta has shortly pubescent lemmas.

Arrhenatherum elatius (L.) P. Beauv. ex J. Presl et C. Presl, $2 \mathrm{n}=28$

Republic of Crimea, surroundings of Yalta, near Foros settlement, $102 \mathrm{~m}$ alt., Quercus forest on the S slope, along the stream, 11 Jun 2016, coll. S.G. Kazanovsky 13156: 6 (IRK, VLA). Distribution: Euro-Mediterranean; cultivated or as alien in many countries. Forest edges and clearings. Described from Europe. Second CN count from Crimea (the first $\mathrm{CN}$ on Crimean plants was published in Probatova et al. 2016: $2 \mathrm{n}=28)$. Tetraploid $(4 \mathrm{x}), \mathrm{x}=7$.

\section{Avena trichophylla K. Koch, 2n = 42}

Republic of Crimea, surroundings of Yalta, near Foros settlement, $145 \mathrm{~m}$ alt., coniferous-broadleaved (Juniperus, Pinus and Quercus) forest on the S slope, forest edge, 11 Jun 2016, coll. S.G. Kazanovsky 13213: 6 (IRK, VLA). Distribution: S Europe - SW Asia. On stony and loamy slopes, in the fields and plantations, waste places, at the roadsides, in settlements. Described from Azerbaidzhan. Second CN count from Crimea (see Prokudin et al. 1977: $2 \mathrm{n}=42$ ). Hexaploid (6x), $\mathrm{x}=7$.

Bromopsis riparia (Rehmann) Holub, 2n $=\mathbf{5 6}$ (counted by A.P. Sokolovskaya)

Republic of Crimea, the Ay-Petri yaila, on the slope, 13 Aug 1974, coll. V.V. Fedyajeva 3958 (a): 9 (VLA). Distribution: E Europe - Caucasus - W Siberia - Middle Asia; alien elsewhere. Dry meadows, steppes, forest clearings, among shrubs. Described from S Ukraine. Octoploid cytotype (8x), $\mathrm{x}=7$; on the whole - variable ploidy $(2 \mathrm{n}=56,70,84-$ Roos 1975; Prokudin et al. 1977; Probatova, Seledets, Rudyka et al. 2012). First CN count from Crimea.

\section{Bromus squarrosus L., 2n $=14$}

Russia, Crimean Peninsula, Sevastopol' city, the historical-archaeological state museum-reserve Khersones Tavricheskii, $55 \mathrm{~m}$ alt., in the ruins of the ancient settlement,
7 Jun 2016, coll. S.G. Kazanovsky 13199: 5 (IRK, VLA). Distribution: Euro-Mediterranean; as alien in many countries and temperate regions. In steppes and semi-deserts, on stony and loamy slopes, sands and gravels, as a weed in plantations, waste places, roadsides, in settlements. Described from Europe. Several CN counts from Crimea (see Prokudin et al. 1977: $2 \mathrm{n}=14)$. Diploid $(2 \mathrm{x}), \mathrm{x}=7$.

\section{Dactylis hispanica Roth, $2 \mathrm{n}=28$}

Russia, Crimean Peninsula, Sevastopol' city, the historical-archaeological state museum-reserve Khersones Tavricheskii, $55 \mathrm{~m}$ alt., among the ruins of the ancient settlement, 7 Jun 2016, coll. S.G. Kazanovsky 13237: 5 (IRK, VLA). Distribution: S Europe, SW Asia, N Africa. Stony and loamy slopes, gravels, forest edges, light forests. Described from Spain. The $2 \mathrm{n}=28$ was already known (see Fedorov 1969). First CN count from Crimea. Tetraploid $(4 \mathrm{x}), \mathrm{x}=7$.

\section{Dasypyrum villosum (L.) P. Candargy, 2n =14}

Republic of Crimea, Sudak town, the Genujezskaya fort, on the slope of the fort wall, $89 \mathrm{~m}$ alt., grass-forb meadow, 26 May 2016, coll. S.G. Kazanovsky 13230: 3 (IRK, VLA). Distribution: Europe, SW Asia. Stony and loamy slopes, sands, among shrubs, on plantations, in roadsides. Described from Greece. Several CN counts from Crimea (see Prokudin et al. 1977: $2 \mathrm{n}=14$ ). Diploid (2x), $\mathrm{x}=7$.

\section{Hordeum bulbosum L., $2 \mathrm{n}=28$}

Republic of Crimea, surroundings of Yalta, near Foros settlement, $145 \mathrm{~m}$ alt., coniferous-broadleaved (Juniperus, Pinus and Quercus) forest on S slope, 11 Jun 2016, coll. S.G. Kazanovsky 13212: 6 (IRK, VLA). Distribution: S Europe, SW Asia. Open stony and loamy slopes, screes, among shrubs, at roadsides and in plantations. Described from Italy. Two CN counts from Crimea (see Prokudin et al. 1977: $2 \mathrm{n}=28)$. Tetraploid $(4 \mathrm{x}), \mathrm{x}=7$.

\section{Hordeum murinum L., 2n $=28$}

Republic of Crimea, Feodossia city, Mitridat Mt., $71 \mathrm{~m}$ alt., sight place, the ruderal vegetation, 26 May 2016, coll. S.G. Kazanovsky 13214 (13246): 4 (IRK, VLA); Republic of Crimea, surroundings of Yalta, outskirts of Alupka town, the Alupkinskii Palace-Park Museum-Reserve, Vorontsovskii Palace, $15 \mathrm{~m}$ alt., the coast of the Black Sea, Aivazovsky rock, among stones, 4 Jun 2016, coll. S.G. Kazanovsky 13243: 7 (IRK, VLA); Republic of Crimea, Simferopol' city, near the airport, as a weed on the lawn, 25 May 2016, coll. S.G. Kazanovsky 13244: 8 (IRK, VLA); Republic of Crimea, Sudak town, the Genujezskaya fort, on the rocks near Konsul'skaya tower, $111 \mathrm{~m}$ alt., at the bottom of the rock, 29 May 2016, coll. S.G. Kazanovsky 13245: 3 (IRK, VLA). Distribution: Europe - SW Asia, alien in Caucasus, Altai, in N America and elsewhere in temperate regions. On sands and gravels, at roadsides, in plantations and settlements. Described from Europe. There were no $\mathrm{CN}$ data for $H$. murinum from Crimea. The same $\mathrm{CN} 2 \mathrm{n}=$ 28 was revealed from Crimea in closely related H. leporinum Link (see Prokudin et al. 1977). The aggregate H. aggr. murinum, very complicated, needs further studies. Tetraploid $(4 \mathrm{x}), \mathrm{x}=7$. 
Koeleria brevis Steven (K. lobata (M. Bieb.) Roem. et Schult.), $2 \mathrm{n}=14$ (counted by A. P. Sokolovskaya)

Republic of Crimea, the Ay-Petri yaila, on stony outcrops, 10 Aug 1974, coll. V.V. Fedyajeva 3964: 9 (VLA). Distribution: E Europe (S part). On limestone outcrops, slopes with steppe vegetation, up to the middle mountain belt. Described from Crimea. Diploid (2x), $x=7$. However, for $K$. lobata the $\mathrm{CN} 2 \mathrm{n}=70$ was reported from Crimea (see Prokudin et al. 1977). The variable ploidy is possible. Further studies of this species are needed.

Lolium loliaceum (Bory et Chaub.) Hand.-Mazz., 2n = 14

Russia, Crimean Peninsula, Sevastopol' city, the historical-archaeological state museum-reserve Khersones Tavricheskii, near the beach "Solnechnyi", $58 \mathrm{~m}$ alt., the grass-forb stony steppe on the slope, 7 Jun 2016, coll. S.G. Kazanovsky 13232: 5 (IRK, VLA). Distribution: S Europe, SW Asia. In steppes and semi-deserts, on stony and loamy slopes, sands and gravels, in coastal zone. Described from Greece. Multiple authors give $2 \mathrm{n}=14$ (see Fedorov 1969). There was CN count from Crimea (see Prokudin et al. 1977: $2 \mathrm{n}=14)$. Diploid $(2 \mathrm{x}), \mathrm{x}=7$.

\section{Poa angustifolia L., $2 \mathrm{n}=56$}

Republic of Crimea, Feodossia city, near the Genujezskaya fort, $51 \mathrm{~m}$ alt., forb steppe, 26 May 2016, coll. S.G. Kazanovsky 13216: 4 (IRK, VLA). Distribution: Eurasia; alien or introduced in N America and other regions. Dry meadows, steppes, forest clearings, on the slopes, stony outcrops, coastal and streamside sands and pebbles, along roadsides, in settlements. Described from Europe. Many $\mathrm{CNs}$ in the abundant literature, in Russia $-2 \mathrm{n}=56,63-64$, c. 70, 70, 70-72. The voucher specimen No 13216 has very narrow contracted panicles with almost smooth panicle branches, and filiform leaf blades; perhaps it represents a still unknown Crimean race. Octoploid (8x), $\mathrm{x}=7$. This $\mathrm{CN}$ $2 \mathrm{n}=56$ is common for $P$. angustifolia, but on the whole this species has variable ploidy. First CN count from Crimea.

Poa crispa Thuill. (P. bulbosa var. vivipara Koeler), $2 \mathbf{n}=\mathbf{2 8}$

Republic of Crimea, Simferopol' city, in vicinity of the airport, as a weed on the lawn, 25 May 2016, coll. S.G. Kazanovsky 13202: 8 (IRK, VLA); Republic of Crimea, surroundings of Feodossia, Kurortnoe settlement, the Karadagskii nature reserve RAS, near the rock Zolotye Vorota, $226 \mathrm{~m}$ alt., broadleaved forest, 27 May 2016, coll. S.G. Kazanovsky 13242: 2 (IRK, VLA); Republic of Crimea, Sudak town, the Genujezskaya fort, on the rocks near Konsul'skaya tower, $111 \mathrm{~m}$ alt., at the bottom of a rock, 29 May 2016, coll. S.G. Kazanovsky 13236: 3 (IRK, VLA). Distribution: predominately Euro-Mediterranean. In steppes and semi-deserts, on stony and loamy slopes, sands and gravels, as alien - at roadsides, in settlements. Described from France. From Crimea 2n $=28$ and 42 were reported (see Prokudin et al. 1977). This taxon is usually recognized as a variety of $P$. bulbosa L., though its area of distribution is larger than in P. bulbosa s. str.; we agree that it is acceptable to take it as a separate species. Tetraploid (4x), $\mathrm{x}=7$. On the whole - the variable ploidy (we revealed $2 \mathrm{n}=$ 28 and 42 in Russia and adjacent countries).

\section{Rostraria cristata (L.) Tzvelev, 2n $=26$}

Republic of Crimea, surroundings of Yalta, outskirts of Alupka town, the Alupkinskii Palace-Park MuseumReserve, Vorontsovskii Palace, $15 \mathrm{~m}$ alt., the coast of the Black Sea, Aivazovsky rock, among stones, 4 Jun 2016, , coll. S.G. Kazanovsky 13235: 7 (IRK, VLA). Distribution: Euro-Mediterranean; alien in other non-tropical countries. Open stony and loamy slopes, sands and gravels, at roadsides. Described from Portugal. First $\mathrm{CN}$ count from Crimea. Diploid (2x), $\mathrm{x}=13$.

\section{Sclerocbloa dura (L.) P. Beauv., 2n $=14$}

Republic of Crimea, surroundings of Yalta, near Nikita settlement, the Nikitskii Botanical Garden, $19 \mathrm{~m}$ alt., on the stony wall, in fissure, 3 Jun 2016, coll. S.G. Kazanovsky 13204: 1 (IRK, VLA); Republic of Crimea, surroundings of Yalta, outskirts of Alupka town, the Alupkinskii PalacePark Museum-Reserve, Vorontsovskii Palace, $15 \mathrm{~m}$ alt., the coast of the Black Sea, Aivazovsky rock, among stones, 4 Jun 2016, coll. S.G. Kazanovsky 13231: 7 (IRK, VLA). Distribution: Euro-Mediterranean; alien in other non-tropical countries. Weedy meadows, pastures, steppe slopes, on plantations, at roadsides and in settlements. Described from S Europe. The species was studied from Turkmenistan and Armenia: 2n = 14 (Sokolovskaya \& Probatova 1978; Nazarova \& Gukassian 2004). Before there were no CN counts from Crimea. Diploid (2x), $\mathrm{x}=7$.

\section{Stipa tirsa Steven (S. longifolia Borbás), $2 \mathrm{n}=44$}

Republic of Crimea, surroundings of Feodossia, Kurortnoe settlement, the Karadagskii nature reserve RAS, near the rock Chertov Palets, $374 \mathrm{~m}$ alt., grass-forb steppe, 27 May 2016, coll. S.G. Kazanovsky 13220: 2 (IRK, VLA). Distribution: Europe,W Siberia. Steppes, forest edges and clearings with steppe vegetation, stony slopes. Described from Ukraine. In Crimea $-2 \mathrm{n}=44$ (see Prokudin et al. 1977). Tetraploid (4x), $x=11$.

\section{Trachynia distachya (L.) Link, 2n = 10}

Russia, Crimea Peninsula, Sevastopol' city, the historical-archaeological state museum-reserve Khersones Tavricheskii, $55 \mathrm{~m}$ alt., in the ruins of the ancient settlement, 7 Jun 2016, coll. S.G. Kazanovsky 13149: 5 (IRK, VLA). Distribution: Europe, SW and S Asia, N and S Africa. On stony and loamy slopes, rocks, screes and pebbles. Described from SW Asia. The same CN $(2 \mathrm{n}=10)$ we revealed in Daghestan, Azerbaidzhan and Turkmenistan; however in Turkmenistan the species also showed $2 \mathrm{n}=28,30$ (Sokolovskaya \& Probatova 1978; Probatova \& Seledets 2008). Two CN counts from Crimea $(2 \mathrm{n}=10-$ see Prokudin et al. 1977). Variable ploidy, with different basic numbers (x $=5,7)$. Perhaps these cytotypes have their own areas of distribution. Diploid $(2 \mathrm{x}), \mathrm{x}=5$.

\section{Vulpia ciliata Dumort., $2 \mathrm{n}=\mathbf{2 8}$}

Russia, Crimean Peninsula, Sevastopol' city, the historical-archaeological state museum-reserve Khersones Tavricheskii, $55 \mathrm{~m}$ alt., in the ruins of the ancient settlement, 7 Jun 2016, coll. S.G. Kazanovsky 13211: 5 (IRK, VLA). Distribution: Euro-Mediterranean. On stony and loamy slopes, on sands and pebbles, in plantations, at roadsides, in 
settlements. Described from Balkan Peninsula. Several CN counts from Crimea $(2 \mathrm{n}=28-$ see Prokudin et al. 1977). Tetraploid (4x), $\mathrm{x}=7$.

\section{ROSACEAE}

*Potentilla jailae Juz. (P. rupestris subsp. jailae (Juz.) Soják), $2 \mathrm{n}=14$

Republic of Crimea, Sudak town, the Genujezskaya fort, on the rocky slope near Konsul'skaya tower, $111 \mathrm{~m}$ alt., 29 May 2016, coll. S.G. Kazanovsky 13207: 3 (IRK, VLA); Republic of Crimea, surroundings of Yalta, Nikita settlement, near Massandra palace, Massandrovskie grottos, $358 \mathrm{~m}$ alt., Pinus and Quercus forest, 5 Jun 2016, coll. S.G. Kazanovsky 13206: 1 (IRK, VLA). Distribution: Crimean endemic. Pine forests on the slopes, mountain pastures (in Crimea). Diploid $(2 \mathrm{x}), \mathrm{x}=7$. Its closely relative species - P. rupestris L., also with $2 \mathrm{n}=14$ (see Májovský et al. 1987). First CN count for the species.

\section{Poterium polygamum Waldst. et Kit., $2 \mathrm{n}=28$}

Republic of Crimea, surroundings of Feodossia, Kurortnoe settlement, the Karadagskii nature reserve RAS, near the rock Zolotye Vorota, $226 \mathrm{~m}$ alt., dry rocky slope, 27 May 2016, coll. S.G. Kazanovsky 13180: 2 (IRK); Republic of Crimea, surroundings of Yalta, near Foros settlement, $145 \mathrm{~m}$ alt., coniferous-broadleaved (Quercus and Juniperus) forest on the S slope, 11 Jun 2016, coll. S.G. Kazanovsky 13233: 6 (IRK, VLA). Distribution: E Mediterranean. On the slopes of hills, on the rocks, the edges of pine forests, among shrubs, in sibljak, and in disturbed habitats. Described from Hungary and Romania. 2n = 16 (?), 28 (Stavropol'skii Krai, Daghestan - see Agapova et al. 1993). First $\mathrm{CN}$ count from Crimea. Tetraploid (4x), $\mathrm{x}=7$.

\section{RUBIACEAE \\ Galium aparine L., $2 \mathrm{n}=44$}

Republic of Crimea, surroundings of Feodossia, Kurortnoe settlement, the Karadagskii nature reserve RAS, near the Biological station, $219 \mathrm{~m}$ alt., broadleaved (Pistacia and Quercus) forest, moist plot, 27 May 2016, coll. S.G. Kazanovsky 13182: 2 (IRK, VLA). Distribution: Euro-Mediterranean; alien in NW Russia, Central Asia, Siberia and N America. As a weed in crops, vegetable gardens, railway embankments, waste places. Described from Europe. Several cytotypes (variable ploidy): 2x, 4x, 6x, 8x and aneuploids (see Fedorov 1969; Májovský et al. 1987). From Crimea this species was studied first. We revealed tetraploid cytotype $-4 \mathrm{x}(\mathrm{x}=11)$.

\section{Galium verticillatum Danthoine ex Lam., $2 \mathrm{n}=22$}

Republic of Crimea, surroundings of Yalta, Nikita settlement, near Massandra palace, Massandrovskie grottos, $358 \mathrm{~m}$ alt., Quercus forest with shrubs on big lumpy placer, 5 Jun 2016, coll. S.G. Kazanovsky 13194: 1 (IRK, VLA). Distribution: E Mediterranean, Caucasus, Asia Minor. Stony steppes, mountain slopes, foothills. Described from Italy (Sicily). We found the only one $\mathrm{CN}$ report (see Fedorov 1969) for this species $(2 n=22)$. In Crimea the species was studied first. Diploid (2x), $\mathrm{x}=11$.

\section{VIOLACEAE}

Viola arvensis Murray, $2 \mathrm{n}=\mathbf{3 4}$

Republic of Crimea, surroundings of Feodossia, Ku- rortnoe settlement, the Karadagskii nature reserve RAS, near the Biological station, $219 \mathrm{~m}$ alt., broadleaved (Pistacia and Quercus) forest, moist plot, 27 May 2016, coll. S.G. Kazanovsky 13208: 2 (IRK, VLA). Distribution: Europe, alien in Asia (Asia Minor, Central Asia, Siberia, Russian Far East) and N America. Meadows, forest clearings; as a weed in plantations and roadsides. Described from Europe. Multiple $\mathrm{CN}$ counts give $2 \mathrm{n}=34$. In Crimea the species was studied first time. Diploid $(2 \mathrm{x}), \mathrm{x}=17$. The genus Viola $\mathrm{L}$. is polybasic $(x=5,6,8,11,13,17,29)$.

\section{CONCLUSION}

Many species were poorly studied as to their $\mathrm{CNs}$, and nearly $66 \%$ of them were not investigated earlier from Crimea. From 42 species most part (22) are diploids or presented by diploid cytotypes, 14 species are tetraploids. The prevalence of diploids indicates the relatively ancient flora. The variable ploidy is obvious in Alyssum trichostachyum, Camelina rumelica, Geranium lucidum, Poa crispa, P. angustifolia, Galium aparine and, without doubt, it might be observed in some more species. In many genera the polybasic situation is known. Most of the species need further karyological studies in the Crimean Peninsula.

\section{ACKNOWLEDGEMENTS}

The authors are grateful to E.G. Rudyka for participation in chromosome numbers determinations.

\section{LITERATURE CITED}

Agapova, N.D., K.B. Arkharova, L.I. Vakhtina, E.A. Zemskova \& L.V. Tarvis 1993. Chromosome numbers in flowering plants of the flora of the USSR: Moraceae-- Zygophyllaceae. Nauka, St.-Petersbourg. 430 pp. (in Russian). [Агапова H.A., Архарова К.Б., Вахтина А.И., Земскова Е.А., Тарвис А.В. 1993. Числа хромосом цветковых растений флоры СССР: семейства Moraceae - Zygophyllaceae. СПб: Наука. 430 с.].

Alexeev, E.B., A.P. Sokolovskaya \& N.S. Probatova. 1987. Taxonomy, distribution and chromosome numbers of the fescues (Festuca L., Poaceae) in the flora of USSR. Byulleten' Moskovskogo obshchestva ispytatelei prirody, Biologia 92(2): 88-95 (in Russian). [А^ексеев Е.Б., Соколовская А.П., Пробатова Н.С. 1987. Таксономия, распространение и числа хромосом овсяниц (Festuca L., Роaceae) флоры СССР // Бюлметень Моск. общ. испыт. прир. ОтА. биол. Т. 92, вып. 2. С. 88-95].

Alexeev, E.B., Sokolovskaya A.P. \& N.S. Probatova 1988. Taxonomy, distribution and chromosome numbers of the fescues (Festuca L., Poaceae) in the flora of USSR. 3. Section Festuca: F. tschujensis - F. beckeri. Byulleten' Moskovskogo obshchestva ispytatelei prirody, Biologia 93(2):90-99 (in Russian). [Алексеев Е.Б., Соколовская А.П., Пробатова Н.С. Таксономия, распространение и числа хромосом овсяниц (Festuca L., Pоасеаe) флоры CCCP. 3. Секция Festuca: F. tschujensis - F. beckeri // Бюлметень Моск. общ. испыт. прир. ОтА. биол. Т. 93, вып. 2. 1988. C. 90-99].

Fedorov, A.A. (ed.) 1969. Chromosome numbers of flowering plants. Nauka, Leningrad. 926 pp. (in Russian). [Хромосомные числа цветковых растений / пол реА. А.А. Федорова. А.: Наука, 1969. 926 с.].

Glagoleva, N.G. \& E.A. Zemskova. 1985. New data on chromosome numbers and on the areas of distribution 
of two Crimean species from the section Empedoclea of Sideritis (Lamiaceae). Botanicheskii Zhurnal 70(5):674-676 (in Russian). [Глаголева Н.Г., Земскова Е.А. 1985. Новые Аанные о чис $а$ ах хромосом и ареалах двух крымских видов секции Empedoclea рода Sideritis (Lamiaceae) // Ботанический журнац. Т. 70, № 5. С. 674-676].

Goldblatt, P. \& D.E. Johnson (eds) 1994. Index to plant chromosome numbers 1990-1991. Monographs in Systematic Botany 51: 1-267.

IPCN Chromosome Reports (http://www.tropicos.org/ Project/IPCN)

Magulaev, A.Yu. 1984. Cytotaxonomical study of some flowering plants of the North Caucasus. Botanicheskii Zhurnal 69(4):511-517 (in Russian). [Магулаев А.Ю. 1984. Цитотаксономическое изучение некоторых цветковых растений Северного Кавказа // Ботанический журнал. Т. 69, № 4. С. 511-517].

Magulaev, A.Yu. 1986. Chromosome numbers in some species of flowering plants of the flora of Crimea and Caucasus. Botanicheskii Zhurnal 71(11):1575-1578 (in Russian). Магулаев А.Ю. 1986. Числа хромосом некоторых виАов цветковых растений фморы Крыма и Кавказа // Ботанический журнац. Т. 71, № 11. C. 1575-1578].

Májovský, J., A. Murîn, V. Feráková, M. Hindáková, T. Schwarzová, A. Uhrîková, M. Váchová \& J. Záborský 1987. Karyotaxonomický prebl'ad flôry Slovenska. Veda, Bratislava. $436 \mathrm{~s}$

Marhold, K., P. Mártonfi, P. Mered'a jun. \& P. Mráz (eds). 2007. Chromosome number survey of the ferns and flowering plants of Slovakia. Bratislava, VEDA. 650 pp.

Nazarova, E.A. \& A.G. Gukassian. 2004. Chromosome numbers in flowering plants of the flora of Armenia. Yerevan. $171 \mathrm{pp}$. (in Russian). [Назарова Э.А., Гукасян А.Г. 2004. Числа хромосом цветковых растений фморы Армении. Ереван. 171 с.].

Patudin, A.V., V.N. Jurtsev \& D.A. Pakaln 1975. Chromosome numbers in some species of the genus Salvia (Lamiaceae). Botanicheskii Zhurnal 60(4):529-534 (in Russian). [Патудин А.В., Юрцев В.Н., Пакалн А.А. 1975. Числа хромосом у некоторых видов рода Salvia (Lamiaceae) // Ботанический журнал. Т. 60, № 4. С. 529-534].

Pimenov, M.G. \& T.A. Ostroumova 2012. Umbelliferae of Russia. KMK, Moscow. 477 pp. in Russian). [Пименов М.Г., Остроумова Т.А. 2012. Зонтичные России. М.: Товарищество научных изданий KMK, 477 с.].

Probatova, N.S., V.Yu. Barkalov \& A.V. Agafonov 2017. Chromosome numbers in some Poaceae species from Russia. Uchonye rapiski Zabaikal'skogo gosudarstvennogo universiteta, biologicheskie nanki 12(1):88-95 (in Russian). [Пробатова Н.С., Баркалов В.Ю., Агафонов А.В. 2017. Числа хромосом некоторых видов злаков (Роасеае) флоры России // Ученые записки Забайкальского госуниверситета. Биологические науки. Т. 12, № 1. C. 88-95].

Probatova, N.S. \& V.P. Seledets. 2008. IAPT / IOPB chromosome data 5 (K. Marhold, ed.). Taxon 57(2): 555-558, E 7-16.
Probatova, N.S., V.P. Seledets \& V.Yu. Barkalov 2015. Chromosome numbers in some species of Poaceae from Russia. Botanica Pacifica 4(1):59-67.

Probatova, N.S., V.P. Seledets \& O.A. Chernyagina 2016. Chromosome numbers in some species of Poaceae from Russia: further studies. Botanica Pacifica 5(2):59-65.

Probatova, N.S., V.P. Seledets, E.G. Rudyka, S.G. Kazanovsky \& V.Yu. Barkalov 2012. Chromosome numbers in some vascular plant species of the flora of Russia. Botanicheskii Zhurnal 97(6):814-831 (in Russian). [Пробатова Н.С., Селедец В.П., Рудыка Э.Г., Казановский С.Г., Баркалов В.Ю. 2012. Числа хромосом некоторых виАОв сосудистых растений фморы России // Ботанический журнал. Т. 97, № 6. С. 814-831].

Prokudin, Yu.N., A.G. Vovk, O.A. Petrova, E.D. Yermolenko \& Yu.V. Vernichenko 1977. Poaceae of Ukraine (Anatomomorphological, karyotaxonomical and eco-phytocoenological survey). Kiev. 518 рp. (in Russian). Прокудин Ю.Н., Вовк А.Г., Петрова О.А., Ермоленко Е.А., Верниченко Ю.В. 1977. З^аки Украины. (Анатомо-морфологический, кариосистематический и эколого-фитоценотический об̈зор). Киев. 518 с.].

Roos, A.V. 1975. Chromosome numbers in some species of grasses. Botanicheskii Zhurnal 60(6):860-864 (in Russian). Роос А.В. 1975. Хромосомные числа некоторых видов зцаков // Ботанический журнал. Т. 60, № 6. C. 860-864.].

Sokolovskaya, A.P. \& N.S. Probatova. 1976. Contribution to karyological characteristics of genera Milium L. и Holcus L. (Poaceae). Botanicheskii Zhurnal 61(7):969-973 (in Russian). [Соколовская А.П., Пробатова Н.С. 1976. К кариологической характеристике родов Milium L. и Holcus L. (Роасеае) // Ботанический журнал. Т. 61, № 7. C. 969-973].

Sokolovskaya, A.P. \& N.S. Probatova. 1978. Chromosome numbers in some grasses (Poaceae) of the flora of the USSR. II. Botanicheskii Zhurnal 63(9):1247-1257 (in Russian). [Соколовская А.П., Пробатова Н.С. 1978. Хромосомные числа некоторых змаков (Роасеае) флоры СССР. II // Ботанический журнал. Т. 63, № 9. C. 1247-1257].

Tonyan C.R. 1968. Chromosome numbers of some species of the genus Centaurea L. Biologicheskii Zhurnal Armenii 21(5):86-96 (in Russian). [Тонян Ц.Р. 1968. Числа хромосом некоторых видов рода Centaurea L. // Биомогический журнал Армении. Т. 21, № 5. С. 86-96].

Yena A.V. 2012. Natural flora of the Crimean Peninsula. N. Orianda, Simferopol', 232 pp. (in Russian). [Ена A.B. 2012. Природная флора Крымского полуострова. Симферополь: Н. Оріанда. 232 с.].

Zefirov, B.M. 1960. New species of Salvia from Crimea (Species nova Salviae e Tauria). Botanicheskie Materialy Gerbaria Botanicheskogo institute im. V.L. Komarova 20: 275-278 (in Russian). [Зефиров Б.М. 1960. Новый виА шалфея из Крыма / / Ботанические материалы Гербария Ботанического института им. В.А. Комарова АН СССР. T. 20. C. 275-278]. 